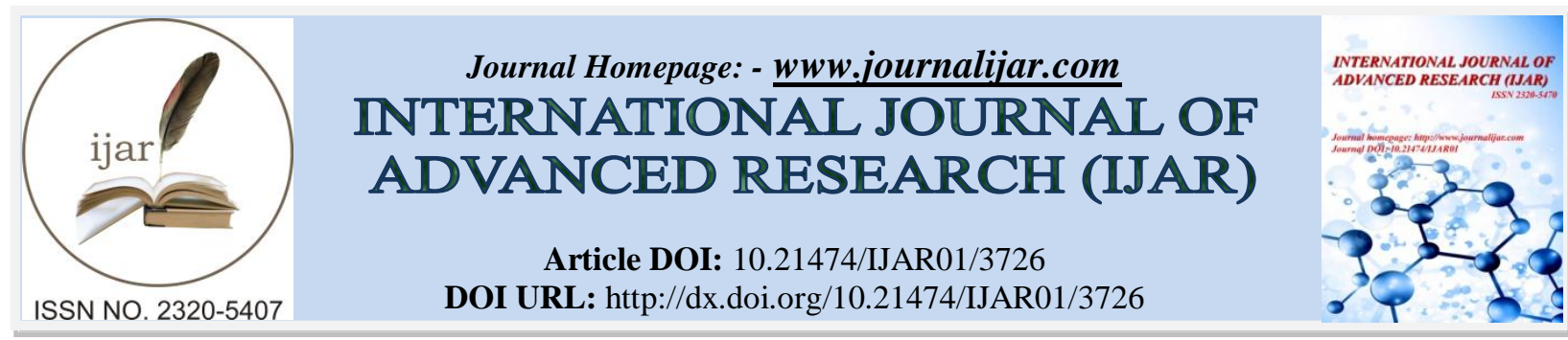

RESEARCH ARTICLE

\title{
A NEW SPECIES OF THE PHYLLANTHUS VASUKII SP. NOV. (PHYLLANTHACEAE) - FROM SOUTHERN EASTERN GHATS OF INDIA.
}

Parthipan, M. ${ }^{1}$, ${ }^{\text {Rajendran. } A^{1} \text {, K. Arumugasamy }}{ }^{2}$, H. L. Jemimma ${ }^{2}$ and G.Thirumaran ${ }^{3}$.

1. Phytodiversity Research Laboratory, Department of Botany, School of Life Sciences.

2. Kongunadu Arts \& Sciences College, Department of Botany, Bharathiar University, Coimbatore- 641046. Tamil Nadu, India.

3. Kanthaswamy Kanda's College, Velur. Tamil Nadu.

\section{Manuscript Info}

(.........................

Manuscript History

Received: 01 January 2017

Final Accepted: 12 February 2017

Published: March 2017

Key words:-

Phyllanthus vasukii, New species,

Namakkal, Southern Eastern Ghats.

\section{Abstract}

A new taxaon, Phyllanthus vasukii sp. nov., is described from the Southern Eastern Ghats. A detailed description, Phenology, Anatomical Characters, Micromorphology of seeds, Distribution and Ecology notes and IUCN status are provided for easy identification.

Copy Right, IJAR, 2017,. All rights reserved.

\section{Introduction:-}

Phyllanthaceae is the second largest segregate of Euphorbiaceae sensu lato, comprising c. 2000 species in 49 genera. Phyllanthaceae includes two subfamilies, Phyllanthoideae and Antidesmatoideae. Phyllanthoideae consists of four tribes and Phyllanthus belongs to the tribe Phyllantheae. Members of Phyllanthaceae are pantropical and include trees, shrubs, phyllocladous taxa, semi - succulents, annual herbs, and even a free floating species. The recent classification of angiosperms recognises five lineages of Euphorbiaceae sensulato at family rank: Euphorbiaceae sensu stricto, Pandaceae Engl. \& Gilg, Phyllanthaceae Martynov, Picrodendraceae Small and Putranjivaceae (APG III, 2009).

Most Phyllanthaceae, are uniform with pinnate venation, entire margins and simple indumentums. Flowers are small and actinomorphic but display great diversity in shape, size and number of floral organs (Hoffmann et al., 2006; Kathriarachchi et al., 2006). The genus Phyllanthus L. was first described by Linnaeus in 1753 and consists of ca.833 species (Govaerts et al., 2000) in the world and is chiefly distributed in moist humid tropics. In India, it is represented by ca. 40 species (Henry \& Santapau, 1973), although Hooker f. (1887) has recorded 56 species from the then British India. In total, 12 species of herbaceous Phyllanthus have been identified in India.

Webster (1955, 1956a, b, 1957, 1958, 1967, 1970 and 1994; Webster and AiryShaw, 1971) has worked exhaustively on Phyllanthus and has provided detailed taxonomy. In course of botanical exploration of local region of Southern Eastern Ghats some exciting specimens of Phyllanthus were collected. After critical examination and perusal of literature, these specimens were determined as belong to a distinct new taxon of the genus Phyllanthus, which is being described here. 


\section{Materials and Method:-}

The plant specimens for collected from various parts of South India and the variations among these two plants were studied using fresh materials as well as herbarium specimens. The morphological and anatomical characters were recorded by examining several specimens of each species with the help of stereomicroscope and inverted phasecontrast microscope, respectively. Details about the distribution, habitat, local name and uses were taken from literature, herbarium data bank and field studies. Anatomical studies were conducted by hand sectioning and stained with safranin stain and glycerine.

\section{Morphological study:-}

The morphological characteristics of the specimens described herein as Phyllanthus vasugii sp.nov. were compared with those of the allied species, $P$. urinaria $\mathrm{L}$.

Table.1:- The difference between of Phyllanthus vasukii sp. nov.and Phyllanthus urinaria.

\begin{tabular}{|c|c|c|}
\hline Attributes & Phyllanthus vasukii sp. nov. & Phyllanthus urinaria.L. \\
\hline Habitat & Shrub & Herb \\
\hline $\begin{array}{l}\text { Leaf size and } \\
\text { shape }\end{array}$ & $\begin{array}{l}5-20 \mathrm{~m} \text { long, } 2-7 \mathrm{~mm} \text { broad, } \\
\text { linear to oblong, When touched, the leaves not } \\
\text { fold. }\end{array}$ & $\begin{array}{l}6-15 \mathrm{~m} \text { long, } 3-15 \mathrm{~mm} \text {, broad oblong, When } \\
\text { touched, the leaves fold in automatically. }\end{array}$ \\
\hline Leaf apex & Mucronate & Mucronate \\
\hline $\begin{array}{l}\text { Stem colour } \\
\text { and form }\end{array}$ & $\begin{array}{l}\text { Dark green, round, not smooth, Branches and } \\
\text { branchlets are stout and erect, tetra gonal, very } \\
\text { rarely branched, glabrous and woody at base. }\end{array}$ & $\begin{array}{l}\text { Reddish-green, not round, } \\
\text { smooth, Branches and branchlets are mostly } \\
\text { weak and drooping, } \\
\text { pentagonal, branched, } \\
\text { glabrous and } \\
\text { woody at base. }\end{array}$ \\
\hline $\begin{array}{l}\text { Fruit and } \\
\text { flower colour }\end{array}$ & $\begin{array}{l}\text { Greenish fruits and whitish green teplas. 6- } \\
\text { capillary fruit. } 6 \text { dehiscent cocci each fruit. }\end{array}$ & $\begin{array}{l}\text { Reddish fruits and reddish green } \\
\text { tepals. } 3 \text {-carpellary fruit. } 3 \text { dehiscent cocci } \\
\text { each fruit. }\end{array}$ \\
\hline $\begin{array}{l}\text { Number of } \\
\text { tepals }\end{array}$ & $\begin{array}{l}\text { Hexatepalous } \\
(6)\end{array}$ & $\begin{array}{l}\text { Hexatepalous } \\
(6)\end{array}$ \\
\hline $\begin{array}{l}\text { Nature of } \\
\text { stipules }\end{array}$ & Greenish and closely attached & Reddish and laterally free \\
\hline Plant height & $\begin{array}{l}\text { Up to } 150 \mathrm{~cm} \\
\text { high }\end{array}$ & Up to $60 \mathrm{~cm}$ high \\
\hline
\end{tabular}

Micromorphology study:-

Table.2:- Difference between anatomical Characters of the Phyllanthus urinaria and Phyllanthus vasukii species (Fig.2.).

\begin{tabular}{|c|c|c|c|}
\hline Part of the plant species & Characters & Phyllanthus urinaria & Phyllanthus vasukii \\
\hline \multirow{3}{*}{ LEAF } & $\begin{array}{l}\text { Number of palisade } \\
\text { parenchyma in the } \\
\text { mesophyll. }\end{array}$ & 2 layer thick & 1 layer thick \\
\hline & $\begin{array}{l}\text { Nature of intercellular } \\
\text { spaces }\end{array}$ & Large & Small \\
\hline & $\begin{array}{l}\text { Nature of xylem cells } \\
\text { within the mid rib }\end{array}$ & $\begin{array}{l}\text { Clustered cells } 2 \text { layers } \\
\text { thick }\end{array}$ & $\begin{array}{l}\text { Clustered cells } 3 \text { layers } \\
\text { thick }\end{array}$ \\
\hline \multirow[b]{6}{*}{ STEM } & Epidermal circumference & Regular angular & Irregular angular \\
\hline & Ridges and Furrows & Present & Present \\
\hline & $\begin{array}{l}\text { Hypodermis } \\
\text { (Collenchyma) }\end{array}$ & $\begin{array}{l}\text { Rectangular } \\
2-5 \text { layers thick on ridges } \\
\text { 1-2 layers thick on furrows }\end{array}$ & $\begin{array}{l}\text { Rectangular } \\
\text { 2-4 layers thick on ridges } \\
2 \text { layers thick on furrows }\end{array}$ \\
\hline & Oil ducts & Absent & Present \\
\hline & Cortex (Parenchyma) & $\begin{array}{l}\text { Oval \& Polygonal } \\
2-5 \text { layers thick }\end{array}$ & $\begin{array}{l}\text { Polygonal } \\
\text { 1-9 layers thick }\end{array}$ \\
\hline & Pericycle (Sclerenchyma) & 2-4 layers thick & 3 layers thick \\
\hline
\end{tabular}




\begin{tabular}{|l|l|l|l|}
\hline & Xylem & $2-5$ elongated cells & $2-8$ elongated cells \\
\cline { 2 - 4 } & Phloem & $3-5$ elongated cells & $2-8$ elongated cells \\
\cline { 2 - 4 } & Ground tissue & Small & Very large \\
\hline \multirow{3}{*}{ ROOT } & Cork cells & $8-11$ cell thick & $2-7$ cell thick \\
\cline { 2 - 4 } & Cortex & $2-4$ cell thick & $6-9$ cell thick \\
\cline { 2 - 4 } & Xylem & $11-43 \mu \mathrm{m}$ & $8-25 \mu \mathrm{m}$ \\
\cline { 2 - 4 } & Phloem & $4-8$ cell thick & $8-11$ cell thick \\
\hline
\end{tabular}

To distinguish Phyllanthus vasukii and Phyllanthus urinaria between lateral, dorsal and ventral ornamentation of the seed surfaces was analyzed by microscopy. Three types of surface ornamentation patterns were presented in the Table-3.

Table.3:- Micromorphology of seeds of features between of Phyllanthus vasukii and Phyllanthus urinaria.

\begin{tabular}{|l|l|l|l|}
\hline \multirow{2}{*}{$\begin{array}{l}\text { Taxa Seed ornamentation } \\
\text { Phyllanthus L. }\end{array}$} & \multicolumn{3}{|c|}{ Seed ornamentation } \\
\cline { 2 - 4 } Phyllanthus vasukii & Dorsal & \multicolumn{1}{|c|}{ lateral } & \multicolumn{1}{c|}{ Ventral } \\
\hline $\begin{array}{l}\text { Transversal ribs, on a } \\
\text { irregular } \\
\text { microverrucose on } \\
\text { ribs, } \\
\text { with valleys }\end{array}$ & $\begin{array}{l}\text { Stellate verrucose } \\
\text { regular concentric } \\
\text { C-shape } \\
\text { alignment, with } \\
\text { crusts }\end{array}$ & $\begin{array}{l}\text { Regular or irregular } \\
\text { concentric C-shape ribs, regular } \\
\text { longitudinal finger-shape rodlets }\end{array}$ \\
\hline Phyllanthus urinaria. & $\begin{array}{l}\text { Transversal ribs, } \\
\text { microverrucose on } \\
\text { ribs, } \\
\text { crusts on valleys }\end{array}$ & $\begin{array}{l}\text { Asymmetrical } \\
\text { longitudinal ribs } \\
\text { valleys, } \\
\text { microverrucose on } \\
\text { ribs, } \\
\text { crusts on valleys }\end{array}$ & $\begin{array}{l}\text { Asymmetrical longitudinal ribs, } \\
\text { microverrucose on ribs sometimes } \\
\text { branched ribs, } \\
\text { crusts on valleys }\end{array}$ \\
\hline
\end{tabular}

Phyllanthus vasukii parthipan et al., sp. nov.

Shrub woody, erect, up to $150 \mathrm{~cm}$ high. Leaf sessile, bipinnate, opposite, entire, leaf let linear to oblong, pale green, 5-20 x 2-7 m, mucronate apex, the base slightly oblique, unequal; stipules linear, very finely puberulous on lower sides leaf margin; lateral veins in 3-5 pairs; reticulation inconspicuous on both sides. Stem green, suffrutescent, sticky angled, rarely branched, glabrous herb, 50-120 cm high, Stem diameter $2.0-2.9 \mathrm{~mm}$. Rarely branchlets up to $35 \mathrm{~cm}$ long, with up to 50 leaves, Flowers, mostly bisexual fascicles, 6 petals, very small, 6 -merous, axillary, ca. $1 \mathrm{~mm}$ in diameter. Higher leaf axils bear only solitary male flowers no paired, with female flowers in the lower axils zig- zag arrangement, single or sometimes paired. Male flowers : Pedicels $0.2-0.5 \mathrm{~mm}$ long; sepals 6, ovate or elliptic, $0.2-0.5$ by $0.5-0.3 \mathrm{~mm}$, white transparent green middle strip; disc glands 6 , star-shaped or orbicular; stamens 3, staminal column 0.1-0.2 mm long, anthers $0.1-0.2 \mathrm{~mm}$ long. Female flowers : pedicels $1.0-$ $1.5 \mathrm{~mm}$ long; sepals 6 , obovate-oblong or lanceolate, $0.5-0.9$ by $0.3-0.6 \mathrm{~mm}$, glabrous, apex acute with broad red pinkish scarious margin with greenish sepals in the middle; disc glands 6; ovary covered with scurfy-tuberculate ; styles $0.2-0.9 \mathrm{~mm}$ long; stigma c. $0.5 \mathrm{~mm}$ long. Fruit green, pedicel $1.0-1.5 \mathrm{~mm}$ long, $0.5-1.5 \mathrm{~mm}$ diam, capsular, depressed globose, densely verrucous, cocci 3 , not spiny. Seeds are transversely ribbed on the back, and sides. Seed 2 in each cocci, $0.8-1.9$ by c. $1 \mathrm{~mm}$ wide, 2 -angled, curved on dorsal side, smooth sand in colour. (Fig.1.)

Flr. \& Fr.: Throughout the year.

Etymology: The new species is named in honour of DR.A.VASUKI, Secretary, Kongunadu Arts \& Sciences College, Coimbatore for her significant contribution in the field of Science.

Distribution: Endemic to Tamil Nadu part of South India.

Habitat and ecology: Growing along the cultivated land, especially wetland field, in moist grassy wetland. Namakal District $\left(11^{\circ} 14^{\prime} \mathrm{N} 78^{\circ} 10^{\prime} \mathrm{E} / 11.23^{\circ} \mathrm{N} 78.17^{\circ} \mathrm{E}\right)$, Tamil Nadu, India. 


\section{Conservation measures:}

The significance of field research is the detection of novel additions to a floristic region, which subsequently improve our understanding of plant biogeography, species diversity. This species is extremely very rare and known only from type locality with limited population density. This should be included in the Red Data Book of Indian plants. The known localities have already covered by Eastern Ghats. However, the new plant should be propagated by using biotechnology method and also to conserve under $e x$ - situ conditions.

\section{Conclusion:-}

In present study, we observed that Phyllanthus urinaria differ from Phyllanthus vasukii and by their height, and leaves numbers, stem, When touched, the leaves not in fold in automatically, Six capillary fruit. 6 dehiscent cocci in each fruit. Anatomical studies also confirmed the new species Phyllanthus vasukii by Nature of intercellular spaces large in leaf, Epidermal circumference in regular angular stem and oil ducts present in stem. Entirely different of number of root arrangement cells, etc. Micromorphology of seeds of features very different between of Phyllanthus vasukii and Phyllanthus urinaria. By this, we confirmed that Phyllanthus vasukii can be treated as a new species due to the presence of variation in both morphological, Micromorphology of seeds and anatomical characteristic features.

\section{Acknowledgement:}

We extend our sincere thanks to Professor and Head, Dept. of Botany, Bharathiar University, Coimbatore.

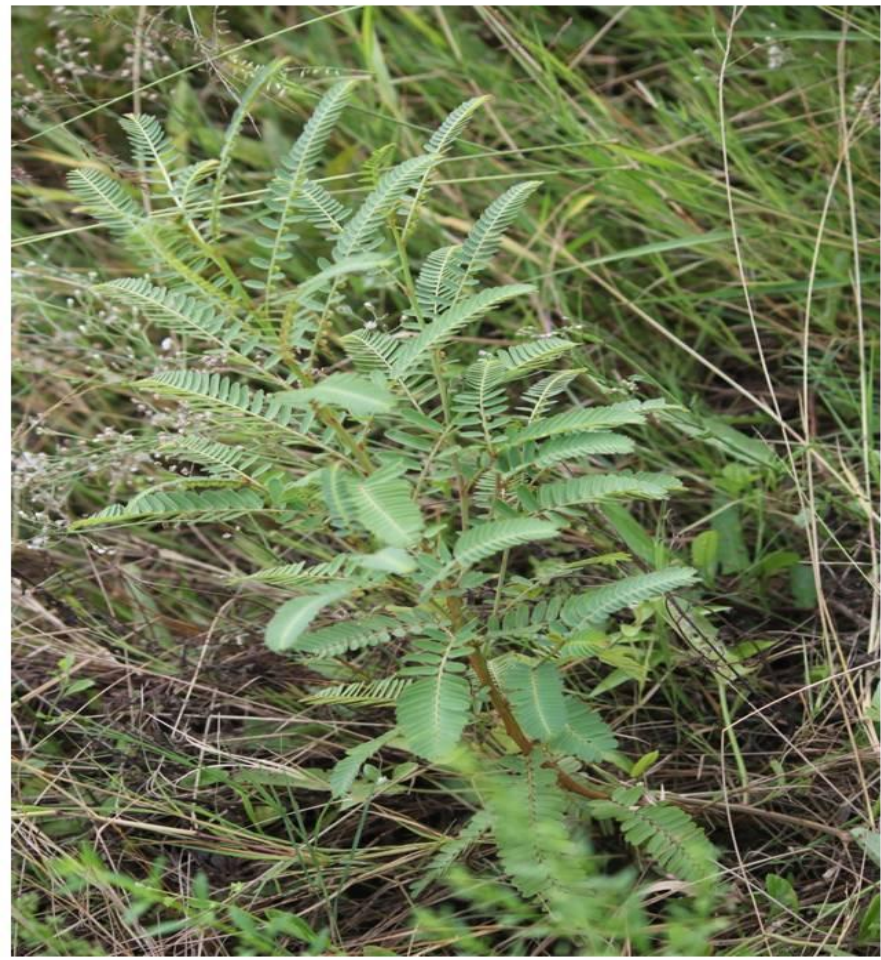

Fig.1:- Phyllanthus vasukii Parthipan et al.., 
Fig-1: Difference between anatomical Characters of the Phytlanthus wrincrie (Daniel et aL, 2015) and Phyllenthus vasuki species.

Phyllawthus vasukit sp. nov
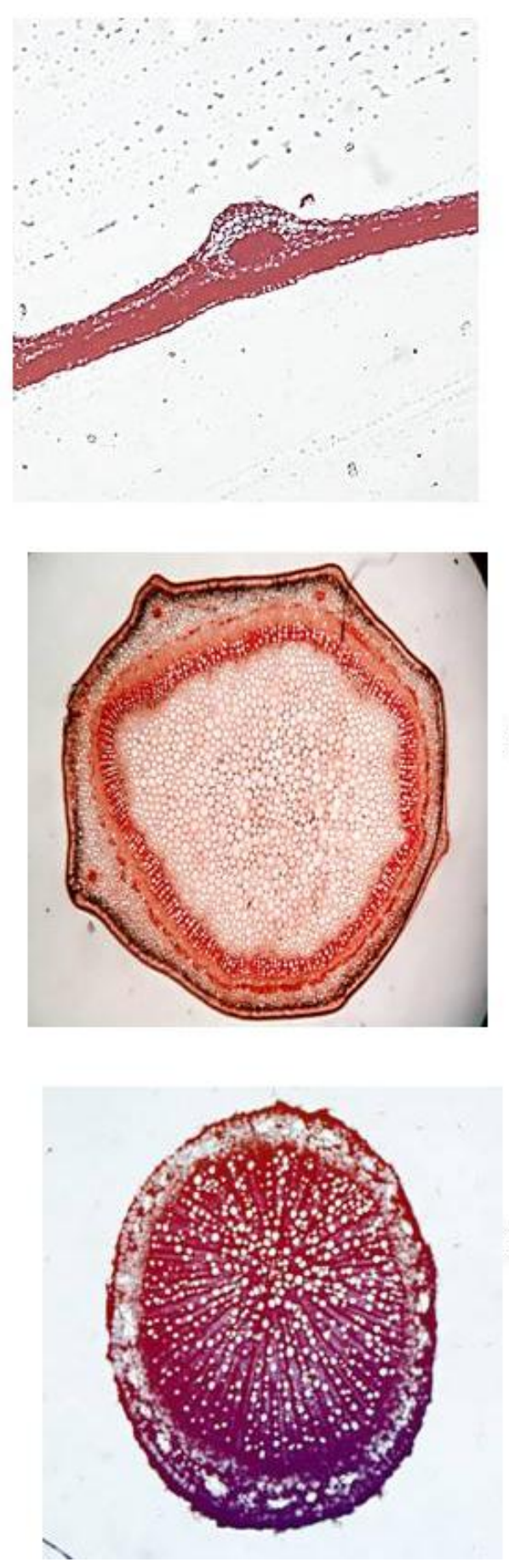

Phyllawthus wrinariaL.
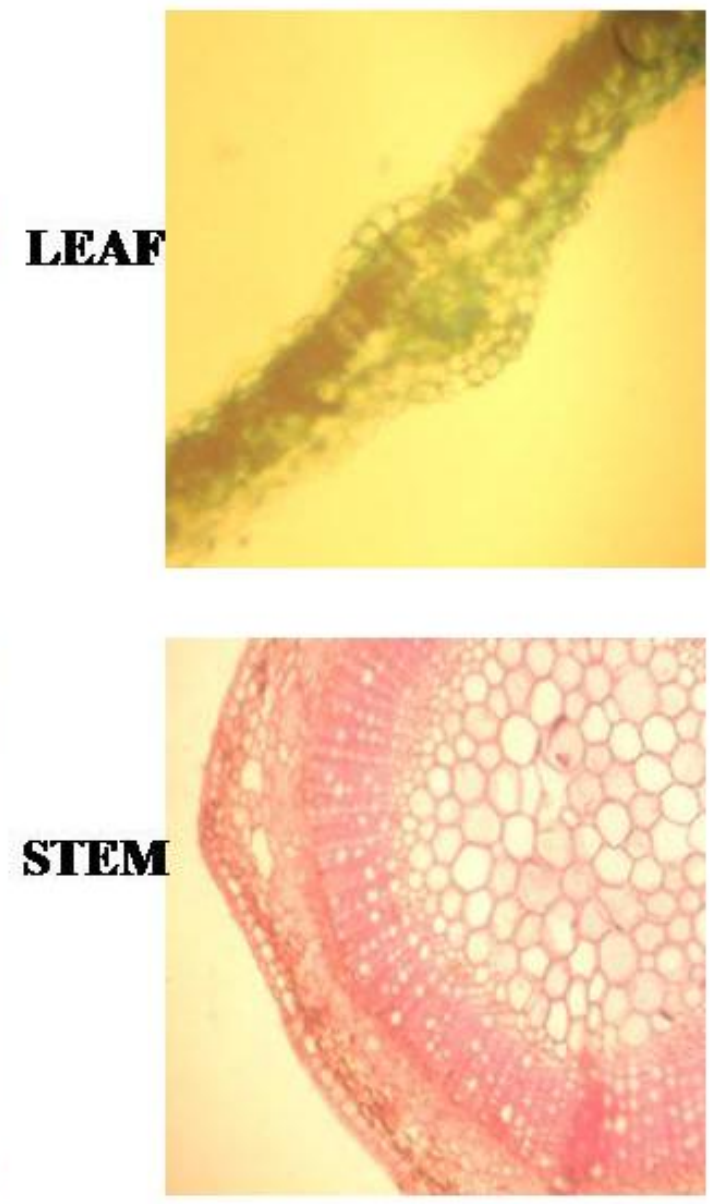

ROOT

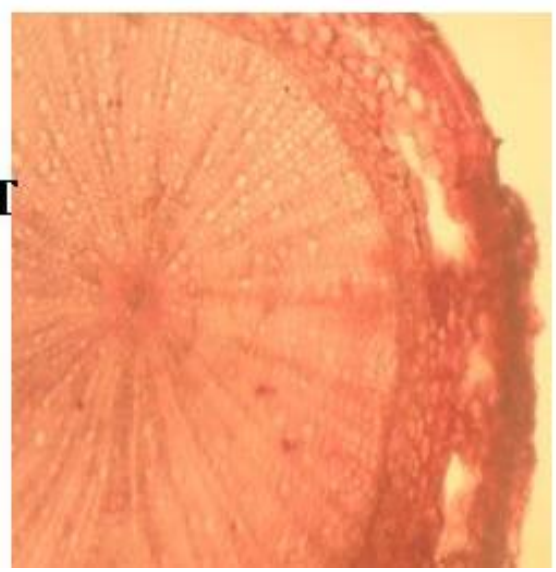




\section{Reference:-}

1. APG III. 2009. An update of the Angiosperm Phylogeny Group classification for the orders and families of flowering plants: APG III. Angiosperm Phylogeny Group. Bot. J. Linn Soc., 161(2):105-121.

2. Daniel Azubuike Awomukwu, Bio Louis Nyananyo, Chiedozie Joel Uka \& Clement Uwabunkeonye Okeke.2015.Identification of the Genus Phyllanthus (Family Phyllanthaceae) in Southern Nigeria using Comparative Systematic Morphological and Anatomical Studies of the Vegetative Organs. Global Journal of Science Frontier Research: C Biological Science Vol.15 (2) 1.0.

3. Kathriarachchi, H., R. Samuel, P. Hoffmann, J. Mlinarec, K. J. Wurdack, H. Ralimanana, T. F. Stuessy and M. W. Chase, 2006. Phylogenetics of tribe Phyllantheae (Phyllanthaceae; Euphorbiaceae sensu lato) based on NRITS and Plastid MATK DNA sequence data. American Journal of Botany, 93(4), 637-655.

4. Hoffmann, P., H. Kathriarachchi and K. J. Wurdack, 2006. A phylogenetic classification of Phyllanthaceae (Malphighiales; Euphorbiaceae sensulato). Kew Bulletin 61: 37 - 53.

5. Govaerts, R., D. G. Frodin and A. Radcliffe Smith, 2000. World checklist and Bibliography of Euphorbiaceae. 4 vols. Royal Botanic Gardens, Kew.

6. Henry, A, N and H. Santapau H, 1973. Dictionary of the flowering plants in India. CSIR, New Delhi.

7. Hooker, J. D., 1887. Phyllanthus In: J. D. Hooker, Flora of British India, Reeve \&Co., London. 5: 285 - 305.

8. Webster, G., L., 1955. Studies of the Euphorbiaceae, Phyllanthoideae I. Taxonomic notes on the West Indian species of Phyllanthus. Contr. Gray. Herb. (Harvard University)., 176: 45-63.

9. Webster, G, L., 1956a. Studies on the Euphorbiaceae, Phyllanthoideae II. The American species of Phyllanthus described by Linnaeus. J. Arnold Arb., 37 (1): 1 - 14.

10. Webster, G, L., 1956b. A monographic study of the West Indian species of Phyllanthus. J. Arnold Arb., 37 (2): 91-122. 217-263, 340-359.

11. Webster, G, L., 1957. A monographic study of the West Indian species of Phyllanthus. J. Arnold Arb., 38: 5164, 170-198, 295-373.

12. Webster, G. L., 1958. A monographic study of the West Indian species of Phyllanthus. J. Arnold Arb., 39: 49 200, 111-212.

13. Webster, G. L., 1967. Genera of Euphorbiaceae in Southern United States. J. Arnold Arb., 48: 303-361, 363430. Webster, G. L., 1970. A revision of Phyllanthus (Euphorbiaceae) in the continental United States. Brittonia., 22: 44-76.

14. Webster, G. L., 1994. Synopsis of the genus and suprageneric taxa of Euphorbiaceae. Ann. Missouri Bot. Gard., 81: 33-144.

15. Webster, G. L and K. H. Airy - Shaw, 1971. A provisional synopsis of the New Guinea taxa of Phyllanthus (Euphorbiaceae). Kew Bull., 26(1): 85-109. 